\title{
PERANAN BIAYA KUALITAS DALAM MENDUKUNG PENGENDALIAN KUALITAS PRODUK PADA UD. MUTIARA RASA JEMBER
}

\author{
Isnay Jannatur Rizka \\ Prodi Akuntansi FE Universitas Muhammadiyah, Jember \\ Email: adinay2507@gmail.com
}

\begin{abstract}
ABSTRAK
Penelitian mengenai Peranan Biaya Kualitas Dalam Mendukung Pengendalian Kualitas Produk Pada UD. Mutiara Rasa Jember merupakan studi kasus pada perusahaan. Tujuan yang ingin dicapai yaitu untuk mengetahui Laporan Biaya Kualitas dalam mendukung Pengendalian Kualitas Produk pada UD. Mutiara Rasa Jember. Metode penelitian laporan data yang digunakan dengan cara mengidentifikasi biaya-biaya untuk menyusun laporan biaya kualitas. Dari hasil laporan biaya kualitas yang diperoleh informasi bahwa biaya kualitas total besarnya berbeda dan cenderung menurun terhadap presentase penjualan. Hasil penelitian menunjukan bahwa usaha peningkatan kualitas, dari pada melakukan kesalahan atau pengerjaan ulang lebih baik melakukan tindakan-tindakan pencegahan untuk mdenghindari kualitas rendah. Sehingga perusahaan dapat meningkatkan atau mempertahankan kepuasan konsumen.
\end{abstract}

Kata kunci: Kualitas, Peranan Biaya Kualitas, Pengendalian Kualitas Produksi

\begin{abstract}
The research about the Role of Costs Quality in Supporting Product Quality Control at UD. Mutiara Rasa Jemberis a case of study in the enterprise. The purpose to be achieve is to find out the report of Costs Quality in supporting Produsct Quality Control at UD. Mutiara Rasa Jember. The method of data report is to identifying cost to make the costs quality report. The researcher get information from the result of costs quality if the total costs of quality is diferrent and occur of the percentage of sales. The research indicated that the effort of quality improvement, than make a mistakes or reworking it is better to take preventive measure to avoid low quality. So, the enterprise can increase or maintain the customers satisfaction.
\end{abstract}

Keywords: Quality, Role of Quality Costs, Production Quality Control 


\section{PENDAHULUAN}

Di era globalisasi saat ini, ,menimbulkan persaingan yang ketat antar pelaku ekonomi. Baik dalam negeri maupun luar negeri. Perusahaan dituntut untuk semakin kreatif menciptakan produk-produk yang tidak hanya mampu bersaing dengan sesama produk dalam negeri, namun juga harus mampu bersaing dengan produkproduk dari negara lain (Bawon, 1907). Dan ternyata perusahaan diharuskan mampu memberikan hasil produksi yang berkualitas (Hartini, 2012). Tanpa adanya kualitas produk yang baik, sudah pasti produk mereka tidak akan bisa laku dipasaran. Tentu saja hal tersebut tidaklah mudah untuk bisa dicapai oleh perusahaan. Sedangkan untuk menghasilkan produk-produk yang berkualitas, perusahaan harus mampu menganilisis biaya kualitas (Kodu, 2013). Yang mana biaya kualitas itu sendiri terdiri dari biaya pencegahan, biaya penilaian, biaya kegagalan internal, dan biaya kegagalan eksternal (Hansen dan Mowen 2007:670-671).

Menururt Hansen dan Mowen (2004:443) biaya kualitas adalah biaya-biaya yang timbul karena mungkin atau telah terdapat produk dengan kualitas yang buruk. Definisi ini mengimplikasikan bahwa berhubungan dengan dua subkategori dari kegiatan-kegiatan yang terkait dengan kualitas yakni kegiatan pengendalian dan kegiatan karena kegagalan (Lestari, 2014). Menurut Hansen dan Mowen (2005:5), kualitas adalah ukuran relatif dari kebaikan (goodness). UD. Mutiara Rasa yang berdomisili di Jember adalah perusahaan yang bergerak di bidang industri makanan khas kota Jember yaitu suwar-suwir.

UD. Mutiara rasa merupakan perusahaan yang mana proses produksinya mengubah bahan baku menjadi barang jadi. Bahan baku di UD. Mutiara Rasa yang masih rendah karena di Indonesia memiliki pergantian musim panas ke musim hujan. Pada saat musim panas kualitas singkong tidak akan baik dan pada saat musim hujan kualitas singkong yang dihasilkan juga tidak baik maka UD. Mutiara Rasa akan mengolah singkong menjadi tape sebaik mungkin agar menghasilkan suwar suwir yang kualitasnya baik. UD. Mutiara Rasa dalam proses produksinya akan mengeluarkan biaya produksi. Jika kualitas bahan baku tidak bagus maka akan mengeluarkan biaya produksi yang cukup tinggi dan jika kualitas bahan baku tidak baik kemungkinan akan mengakibatkan produk suwar suwir menjadi cacat atau rusak.

\section{METODE PENELITIAN}

Jenis data yang dikumpulkan oleh peneliti menggunakan Data Primer dan Data Sekunder. Teknik pengumpulan data menggunakan Wawancara dan Dokumentasi. Teknik analisis data yaitu (1) Mengidentifikasi biaya-biaya yang terjadi kedalam biaya kualitas, Mengklasifikasikan atau mengelompokkan biaya kualitas kedalam: a) Biaya Pencegahan, b) Biaya Penilaian, c) Biaya Kegagalan Internal, d) Biaya Kegagalan Eksternal. (3) Menyusun laporan biaya kualitas, (4) Membandingkan laporan biaya kualitas dengan anggaran biaya kualitas, (5) Menyimpulkan hasil laporan hasil dan laporan anggaran biaya kualitas.

\section{HASIL DAN PEMBAHASAN Hasil Penelitian}

Berdasarkan hasil wawancara dan data yang ada pada UD. Mutiara Rasa Jember, maka dapat diidentifikasi biaya-biaya yang termasuk kedalam biaya kualitas, yaitu sebagai berikut:

\section{Biaya Pencegahan}

Biaya Pencegahan yaitu biaya yang dikeluarkan untuk mencegah terjadinya produk yang cacat atau tidak sesuai dengan spesifikasi yang ditetapkan. Biaya pencegahan ini terdiri dari: a) Biaya Program Pelatihan Kualitas dan b) Biaya Pemilihan dan Mengevaluasi Bahan Baku

2. Biaya Penilaian

Biaya Penilaian yaitu biaya yang terjadi untuk menentukan apakah produk yang dihasilkan sesuai dengan spesifikasi yang ditetapkan. Biaya penilaian terdiri dari: a) Biaya Pemeriksaan atau Pengujian Bahan 
Baku, b) Biaya Pemeriksaan Kemasan, c) Biaya Pengawasan Kegiatan Produksi

3. Biaya Kegagalan Internal

Biaya Kegagalan Internal yaitu biaya yang terjadi ketika produk tidak sesuai spesifikasi dapat dideteksi sebelum dikirimkan ke konsumen. Biaya kegagalan internal terdiri dari: a) Biaya Pemeriksaan Ulang, b) Biaya Pengerjaan Ulang

\section{Biaya Kegagalan Eksternal}

Biaya Kegagalan Eksternal yaitu biaya yang terjadi karena produk yang tidak sesuai spesifikasi dideteksi setelah dikirimkan ke konsumen. Biaya kegagalan eksternal terdiri dari: a) Biaya Keluhan Konsumen dan b) Biaya Garansi

Tabel 01 Laporan Biaya Kualitas Dalam satuan Rupiah

\begin{tabular}{|c|c|c|}
\hline \multirow{3}{*}{ Keterangan } & \multicolumn{2}{|c|}{ Total Penjualan dalam satu tahun } \\
\hline & $\%$ & Nilai \\
\hline & 100 & 817.300 .000 \\
\hline \multicolumn{3}{|l|}{ 1. Biaya Pencegahan } \\
\hline a. Biaya Program Pelatihan Kualitas & $0,06 \%$ & 500.000 \\
\hline $\begin{array}{l}\text { b. Biaya Pemilihan dan Evaluasi Pemasok } \\
\text { Bahan baku }\end{array}$ & $1,46 \%$ & 12.000 .000 \\
\hline Total Biaya Pencegahan & $1,52 \%$ & 12.500 .000 \\
\hline \multicolumn{3}{|l|}{ 2. Biaya Penilaian } \\
\hline $\begin{array}{l}\text { a. Biaya Pemeriksaan dan Pengujian } \\
\text { Bahan Baku }\end{array}$ & $0,22 \%$ & 1.800 .000 \\
\hline b. Biaya Pemeriksaan Kemasan & $1,10 \%$ & 9.000 .000 \\
\hline c. Biaya Pengawasan Biaya Produksi & $1,65 \%$ & 13.500 .000 \\
\hline Total Biaya Penilaian & $2,97 \%$ & 24.300 .000 \\
\hline \multicolumn{3}{|l|}{ 3. Biaya Kegagalan Internal } \\
\hline a. Biaya Pemeriksaan Ulang & $1,10 \%$ & 9.000 .000 \\
\hline b. Biaya Pengerjaan Ulang & $1,46 \%$ & 12.000 .000 \\
\hline Total Biaya Kegagalan Internal & $2,56 \%$ & 21.000.000 \\
\hline \multicolumn{3}{|l|}{ 4. Biaya Kegagalan Eksternal } \\
\hline a. Biaya Keluhan Konsumen & $0,30 \%$ & 2.500 .000 \\
\hline b. Biaya Garansi & $1,47 \%$ & 12.000 .000 \\
\hline Total Biaya Kegagalan Eksternal & $1,77 \%$ & 14.500 .000 \\
\hline
\end{tabular}

Sumber: UD. Mutiara Rasa Jember 2017 (diolah peneliti)

\section{Pembahasan Hasil Penelitian}

Pengendalian biaya kualitas yang dilakukan dengan memanfaatkan anggaran biaya kualitas dengan memperhitungkan jumlah hasil yang didapat dari biaya tersebut. Dalam penyusunan anggaran biaya kualitas UD. Mutiara Rasa Jember menentukan besarnya yang ditetapkan di setiap biaya-biaya yang dikeluarkan sehingga UD. Mutiara Rasa Jember diharapkan dapat mengendalikan biaya yang sudah direalisasikan. Dan karena itu UD. Mutiara Rasa Jember menggunakan anggaran biaya kualitas sebagai salah satu alat yang mempunyai peran penting yaitu sebagai alat untuk mendukung pengendalian kualitas produk.

Dari keempat jenis biaya kualitas yaitu, biaya pencegahan, biaya penilaian, biaya kegagalan internal dan biaya kegagalan eksternal dari bulan januari sampai dengan bulan desember tahun 2017 
masing-masing jumlahnya berbeda. Dari hasil pengklasifikasian biaya kualitas diperoleh informasi bahwa biaya kualitas jumlah setiap bulannya berubah-ubah terhadap presentase dari penjualan. Jumlah besarnya biaya kualitas setiap bulan mengalami kenaikan dan perununan di bulan tertentu.

Dapat dilihat dari rekapitulasi di empat jenis biaya kualitas, yaitu sebagai berikut: Biaya pencegahan yang dikeluarkan oleh UD. Mutiara Rasa Jember dalam total penjualan satu tahun yaitu $1,52 \%$. Biaya yang dikeluarkan sebesar Rp. 12.500.000, jadi dapat dikatakan bahwa Biaya pencegahan mendukung dalam pengendalian kualitas produk. Naik turunnya biaya pencegahan berpengaruh pada terjadinya peningkatan kualitas produk. penurunan. Biaya penilaian yang dikeluarkan oleh UD. Mutiara Rasa Jember yaitu 2,97\% dan biaya yang dikeluarkan sebesar Rp. 24.300.000. Serta biaya penilaian sangat efektif dalam mendukung pengendalian produk pada UD. Mutiara Rasa Jember. Karena selama tahun 2017 UD. Mutiara Rasa Jember tidak mengalami kenaikan dalam pengeluarannya. Biaya kegagalan internal juga stabil pada UD. Mutiara Rasa Jember karena selama pengeluarannya tidak mengalami kenaikan yang pengeluarannya 2,56\% dan sebesar Rp. 21.000 .000 . Karena UD. Mutiara Rasa Jember dalam proses produksinya tidak terlalu banyak masalah akan tetapi setiap bulannya mengeluarkan biaya yang sama pada biaya kegagalan internal. Biaya pemeriksaan ulang dapat dinilai dari pengembalian produk terbanyak dikemasan tas berat $1 \mathrm{~kg}$ yaitu sebesar 250 kemasan yang presentasenya adalah $2,03 \%$. Biaya pengerjaan ulang dapat dinilai dari seberapa besar produk cacat yang dikembalikan yaitu dalam kemasan batangan $1 \mathrm{~kg}$ karena produk tersebut banyak mengalami kerusakan. Produk cacat tersebut sebesar 73 yang presentasenya adalah $0,86 \%$. Biaya kegagalan eksternal yang pengeluarannya $1,77 \%$ dan biaya nya sebesar Rp. 14.500.000. Keluhan konsumen yang banyak apalagi pada bulan juli yaitu setelah lebaran karena pada saat itu UD. Mutiara Rasa Jember tidak memproduksi begitu banyak jadi banyak keluhan konsumen yang terjadi. Biaya garansi yang dikeluarkan selama tahun 2017 juga stabil karena tidak mengalami kenaikan.

\section{PENUTUP \\ Simpulan}

Berdasarkan data-data dan waawancara yang dilakukan oleh peneliti, maka peneliti mengambil kesimpulan sebagai berikut: (1) Biaya ini terdiri dari biaya program pelatihan kualitas dan biaya pemilihan dan evaluasi pemasok bahan baku. Pengeluaran biaya pencegahan ini hanya $1,52 \%$ dari total penjualan selama satu tahun. Biaya pencegahan ini mendukung dalam pengendalian kualitas produk pada UD. Mutiara rasa Jember. (2) Biaya ini terdiri dari biaya pemeriksaan dan pengujian bahan baku, biaya pemeriksaan kemasan, dan biaya pengawasan kegiatan prduksi. Pengeluaaran biaya penilaian ini sebesar $2,97 \%$ dari total penjualan selama satu tahun. Biaya penilian ini stabil dalam pengeluarannya. Jadi biaya penilaian efektif serta mendukung dalam pengendalian kualitas produk pada UD. Mutiara rasa Jember. (3) Biaya ini terdiri dari biaya pemeriksaan ulang dan biaya pengerjaan ulang. UD. Mutiara Rasa Jember dalam pengeluaran biaya internal nya yaitu sebesar $2,56 \%$ dari total penjualan selama satu tahun dan juga stabil karena dalam produksinya tidak terlalu banyak masalah. Tetapi dilihat dari biaya pemeriksaan ulang yaitu sebesar $2,03 \%$ dari kemasan yang terjual, dan biaya pengerjaan ulang yaitu sebesar $0,86 \%$ dari kemasan yang terjual. Jadi biaya kegagalan internal ini mendukung dalam pengendalian produk pada UD. Mutiara Rasa Jember. (4) Biaya ini terdiri dari biaya keluhan konsumen dan biaya garansi. Biaya kegagalan eksternal pengeluarannya yaitu sebesar $1,77 \%$ dari total penjualan. Walaupun biaya ini mengalami kenaikan dan biaya garansi di UD. Mutiara Rasa Jember dalam pengeluarannya stabil. Jadi biaya kegagalan eksternal ini mendukung dalam pengendalian kualitas produk pada UD. Mutiara Rasa Jember. 


\section{Saran}

Dari kesimpulan diatas penulis memberikan saran kepada UD. Mutiara Rasa Jember untuk mengatasi permasalahan yang dihadapi: UD. Mutiara Rasa Jember sebaiknya lebih teliti dan lebih rinci dalam pencatatan biaya kualitas yang terjadi ditahun berikutnya agar perusahaan dapat melakukan pengukuran terhadap biaya kualitas yang akan terjadi. Dan sebaiknya biaya-biaya yang dikeluarkan oleh perusahaan dilaporkan dalam suatu laporan biaya kualitas.

\section{DAFTAR RUJUKAN}

Bawon, D.N.P., Sondakh, J.J. and Mawikere, L., 1907. Penerapan biaya kualitas untuk meningkatkan efisiensi biaya produksi pada pt. pertani (Persero) cabang sulawesi utara. GOING CONCERN, p.48.

Dunia, Firdaus Achmad dan Abdullah Wasilah. 2012. Akuntansi Biaya. Edisi 3, Jakarta : Salemba Empat.

Dewi, Sofia Prima dan Septian Bayu Kristanto. 2015. Akuntansi Biaya. Bogor : Inmedia.

Hansen dan Mowen. 2004. Manajemen

Biaya, Edisi Bahasa Indonesia. Buku

Kedua. Jakarta : Salemba Empat.

Hansen dan Mowen . 2005. Management Accounting. Edisi 7. Jakarta : Salemba Empat.

Hartini, S., 2012. Peran inovasi: pengembangan kualitas produk dan kinerja bisnis. Jurnal Manajemen dan Kewirausahaan, 14(1), pp.8390.

Kodu, S., 2013. Harga, kualitas produk dan kualitas pelayanan pengaruhnya terhadap keputusan pembelian mobil Toyota avanza. Jurnal EMBA: Jurnal Riset Ekonomi, Manajemen, Bisnis dan Akuntansi, 1(3).

Lestari, R.M.E. and Hakim, M.M., 2014. Pengaruh Biaya Kualitas Terhadap Tingkat Penjualan Pada PT Mitra Sejati Mulia Industri. JIAFE (Jurnal Ilmiah Akuntansi Fakultas Ekonomi), 6(2), pp.34-41.
Martusa, R. and Haslim, H.D., 2011. Peranan Analisis Biaya Kualitas dalam Meningkatkan Efisiensi Biaya Produksi. Maksi, 4(2).

2007. Akuntansi Manajemen. Edisi 7. Jakarta : Salemba Empat

Prihantoro, Rudy. 2012. Konsep Pengendalian Mutu. Bandung : Remaja Rosdakarya.

Putri, B.W., 2012. Penentuan Kualitas Audit Berdasarkan Ukuran Kantor Akuntan Publik dan Biaya Audit. Jurnal Ilmiah Mahasiswa Akuntansi, 1(4), pp.60-64.

Sandag, N.E., Tinangon, J. and Walandouw, S.K., 2014. Analisis Biaya Kualitas Dalam Meningkatkan Profitabilitas Perusahaan Pada Cv Ake Abadi Manado. Jurnal EMBA: Jurnal Riset Ekonomi, Manajemen, Bisnis dan Akuntansi, 2(2).

Sugiyono. 2012. Metode Penelitian Kuantitatif, kualitatif, dan $R \& D$. Bandung : Alfabeta.

Susmita, P.R. and Supadmi, N.L., 2016. Pengaruh Kualitas Pelayanan, Sanksi Perpajakan, Biaya Kepatuhan Pajak, Dan Penerapan E-Filing Pada Kepatuhan Wajib Pajak. E-Jurnal Akuntansi, pp.1239-1269.

Usman, R., 2011. Pengaruh Biaya Kualitas terhadap Kinerja Balanced Scorecard Perusahaan Manufaktur Berskala Besar. Sumber, 133(017), p.9.

Yamit, Zulian. 2010. Manajemen Kualitas Produk \& Jasa. Edisi Pertama. Yogyakarta : Ekonisia.

Wahyuningtias, K.A., 2013. Pengaruh Biaya Kualitas Terhadap Produk Rusak Pada CV. Ake Abadi. Jurnal EMBA: Jurnal Riset Ekonomi, Manajemen, Bisnis dan Akuntansi, 1(3). 